\title{
Minutes of April 2016, APSA Council Meeting
}

\author{
Saturday, April 9, 2016 \\ Chicago, IL - Chicago University Club
}

\section{MEMBERS PRESENT}

President: Jennifer Hochschild; PresidentElect: David Lake; Vice Presidents: Frank Baumgartner and Martha Finnemore; Treasurer: Taeku Lee; and Secretary: Suzanne Mettler

Council Members: Michelle Deardorff, Maria Escobar-Lemmon, Roxanne Euben, Rodney E. Hero, Amaney Jamal, Frances Lee, Brett Ashley Leeds, David Lublin, Marc Lynch, James Mahoney, Byron D’Andra Orey, Bo Rothstein, Cameron Thies, Caroline Tolbert, and Mark Warren

American Political Science Review Lead Editor: John Ishiyama; Perspectives on Politics Editor-in-Chief: Jeffrey Isaac; and PS: Political Science \& Politics Editors: Phillip Ardoin and Paul Gronke

APSA Staff: Kara Abramson, Regina Chavis, Patrick French, Dan Gibson, Morgan Johnson, Kimberly Mealy, Teka Miller, Steven Rathgeb Smith, Betsy Super, and Barbara Walthall

Not in Attendance: Kimberly Morgan, David Obey, Tasha Philpot, Deborah Schildkraut, David Stasavage

\section{CALL TO ORDER}

APSA President Jennifer Hochschild called the meeting to order on April 9, 2016 at 8:30am.

\section{CONSENT AGENDA}

Motion to pass Fall 2015 Council Meeting Minutes and Consent Agenda was proposed, seconded, and approved unanimously.

\section{PRESIDENT'S REPORT}

Hochschild discussed her goals to improve the annual meeting, as well as improving the manner in which APSA serves its members who are not at large research institutions.

\section{TREASURER'S REPORT}

T. Lee reported that APSA is in sound financial shape. The Association has \$30.4 million in investments; \$13.7 million in the trust and development portfolio; $\$ 14.2$ million in the Congressional Fellowship Program trust portfolio; and is projecting revenue of \$2.36 million from operations. Lublin questioned if APSA is profitable without reserve transfers. T. Lee responded that the Association's biggest loss is from losses to investments. Chavis clarified T. Lee's answer and assured Lublin of APSA's good financial standing.

\section{EXECUTIVE DIRECTOR'S REPORT}

Smith updated the Council on the status of editor searches, the distribution of the Journal of Political Science Education (JPSE) as a member benefit, renegotiations of the Cambridge University Press, and Taylor and Francis contracts, as well as the digitization of APSA journals. Smith highlighted the new Annual Meeting format and encouraged feedback. Gronke, Lynch, and Rothstein expressed their concerns about the old Annual Meeting format. Hochschild and Smith discussed the issues that arise due to the poster format.

Smith gave an update on APSA's Diversity and Inclusion programs including the Ralph Bunche Summer Institute, a new virtual issue on diversity in the profession, and the Committee of the Status of Women in the Profession's microsite. F. Lee enquired if APSA funds support RBSI. Smith explained the funding for RBSI by APSA and Duke University. Jamal asked if APSA could spend the funds set aside for RBSI on other minority programs if the NSF funds the institute again. Super expressed APSA would wait for confirmation of funding before moving forward on any options.

Smith updated the Council on the status of MENA workshops in Beirut, a partnership with the US Korea Institute at SAIS, a partnership with the Mexican Political Science Association (AMECIP), as well as the staff exchange between APSA and the Political Studies Association of the United Kingdom.

Smith gave updates on the Wilson, Dahl, and Lowi awards; recent research reports that have been produced; a review of the conference submission system; as well as the current building maintenance taking place at the APSA headquarters. Rothstein asked if Smith could talk about current National Science Foundation funding for political science. Abramson gave a summary of FY 2016 appropriations for NSF. Lynch enquired if the change to the annual meeting date answered the member's needs. Smith discussed future planned meeting sites. Lynch would have liked to send out another membership survey asking opinions on the Annual Meeting timing and location. Smith explained the issues with sending out a survey in 2022 when planning for the Annual Meeting is done so far in advance. Leeds believed the plan is to move off Labor Day in 2023, but then to move back. Smith explained the process for soliciting bids and ideas for rotating on and off Labor Day. Escobar-Lemmon believed that this process needs to be properly communicated to the members. Leeds believed switching the date and then moving back without further information could make members upset as it could appear as a gesture rather than a change. Tolbert and Gronke would have liked to send out a small sample survey to gauge member response to these Annual Meeting changes. Lynch, Hochschild, Smith, and Gronke discussed the issues that may arise around issuing a survey to gauge opinions on the non-Labor day date.

\section{GOVERNANCE REFORM}

Lake gave background to the work that has been done recently by the Ad Hoc Committee for Governance Reform. He then explained the issues that have surrounded the proposed amendments. Hochschild asked for proposed changes to the new proposed amendments. Ishiyama asked what role the editors would have under the proposed new bylaws. Lake explained the newly proposed Council committees and their role as non-voting members of Council. Ishiyama believed that the editors play a vital role. Lake believed that even after the creation of the Council publications committee, the editors would remain in constant contact with Council. Ishiyama asked if the committee had already been created. Lake affirmed that it had. Hochschild elaborated on the intended interaction between the editors and the committee.

Baumgartner, Hochschild, and Lake discussed the ability ofAPSA to take positions on issues of public policy. Smith clarified what APSA can take positions on based on the current constitution. F. Lee asked Lake for clarification on the amendment in regards to making statements of public opinion in regards to public policy. Lake explained that 
the Ad Hoc Committee intended to make the new amendment as open as possible. Baumgartner believed that if this policy limits APSA from making comments about public policy than this will really limit the Association. Escobar-Lemmon reminded the Council that not saying or doing anything is also a statement. Lake indicated that the proposed language had been reviewed by the attorney, and that Council has the option to agree or disagree with the attorney's comments. Jamal asked how this affects speaking about the NSF. Lake, Hochschild, and Smith discussed.

Lynch suggested that the new language be extended to encompass all ethical implications that the Association may have. Lake suggested creating a list of all the things the Association can do. Warren agreed with Lynch, but believed a list would only limit APSA more. Tolbert discussed her desire to remove public policy from the amendment. Lake assured the Council that this new language was thought over repeatedly by the committee, and reminded the Council what a "yes" or "no" vote would do, and how a "no" vote would play out at the all-member business meeting. Lublin expressed his concern with how the new language will be perceived by the membership. T. Lee asked for clarification regarding the "yes" or "no" vote and what they will cause, and how he feels regarding the bylaws. Hochschild explained the Ad Hoc committee's recommendation and what a "yes" vote would entail. F. Lee believed that the old language should be kept. Baumgartner asked for clarification regarding the motion made by F. Lee. F. Lee motioned to keep old language of Article II, Section 2, and the motion was seconded. Tolbert asked for clarification on the proposed motion. Hochschild and Lake explained how this motion differs from Lake's proposal. T. Lee, Leeds, Lake, and F. Lee discussed the proposed language and the affects they believe it will have on APSA. Hochschild clarified the motion and asked for votes to retain old language per F. Lee's motion. The motion failed.

Hochschild then prompted the voting of the Ad Hoc Committee's recommendation and refreshed the Council on what was being voted on. Jamal asked for further clarification on the two opposing versions and what was different in the new language. Hochschild, Lake, and Smith explained the new language. Move to adopt the Ad Hoc Committee on Governance reforms amendments to the new bylaws. Motion was seconded and debated. Motion failed.
Lake proposed going back to the committee on the specific question of Article II, Section 2 and rewriting the amendment with the comments from Council, and Smith suggested having an electronic ballot vote. Motion made to approve the bylaws as put forward by the Ad Hoc Committee on Governance Reform in the Council book as they now stand was seconded, discussed, and approved unanimously.

\section{APSR EDITOR}

Hochschild updated the Council on the work that has been done on the APSR editorial team negotiations, how the editorial board is composed, and described the proposal and decisions before Council today. Mahoney enquired what will happen if the current proposal is not accepted, and if any amendments can be made to the current team. Hochschild explained that after July 1 there would be no editor and that it is unlikely that the proposed team can be changed. Warren, Euben, Mahoney, and Lynch believed that the team should be more diverse, and described what they each would like to see on the team. Hochschild then explained what thought process was used in selecting the proposal, and reminded the Council that they previously approved the original editorial proposal. Jamal asked what decision would need to be made right now, and if any changes can be made to the editorial team. Smith explained the process and suggested to the Council that this team is not all that different from the team approved previously by the Council. Lynch stated that this proposal should be treated as a completely new proposal. T. Lee questioned if a "no" vote would lead the editors to reassess their proposal. Smith explained his belief that a "no" vote would risk the contract in its entirety. Tolbert voiced her concerns with the process for the editorial team and wanted to know what other options the Council has. Euben did not feel comfortable voting on this without the Council having a part in selecting the editorial team, and clarified the motion she was making. Lake explained that making suggestions to the editorial board is not an uncommon practice. Jamal expressed her concerns with the editorial team's proposed quota system.

Baumgartner believed that since this proposal had already been approved then a request for revision would serve as a complete rejection of the proposal. Smith, Lake, and Hochschild explained the process they had gone through with the editorial team and what a "no" vote would entail and what it would imply. T. Lee expressed his belief in what a "no" vote would entail. Leeds questioned how many times APSA had spoken to König's editorial team members. Hochschild reported that most conversation has been with König and Benoit. Lublin highlighted the positive aspects of diversity present in the editorial team, and he agreed with the comments that Leeds had made. Lynch and Smith discussed the voting process that Council needs to complete.

Council broke for lunch.

Hochschild explained that conversation during the lunch break yielded the idea of a two-year contract that gave clear signals regarding desired changes to the editorial board. Council discussion ensued. Hochschild then proposed starting with a vote on the four-year contract. She put forward a motion for a four-year agreement, set of editors, review in two years, with an eye toward advice and direction not termination, and Council approval of editorial board. Deardorff seconded the motion, the Council discussed, and the motion failed.

Lublin motions for three years, consistent regular reviews, seven people on the editorial team, and Council approval of the editorial board per current practice. Jamal seconded, Council discussed, and the motion passed. Hochschild announced that the review process will need to be established.

Hochschild updated the Council on the amended schedule for the rest of the meeting.

\section{NEW COMMITTEE/COMMITTEE UPDATES DISCUSSION}

Hochschild expressed that one of her main goals as president had been to broaden inclusion in the Association, including those who have not always felt incorporated in the Association. Hochschild would have liked to create an Ad Hoc Committee that would create a report and study participation in APSA by adjunct/contingent faculty. The motion to create the committee was made, seconded, and approved unanimously.

Smith discussed the proposed graduate student committee. Hochschild expressed that there were a high turnover of graduate students in the Association. Smith explained the committee's goals, the criteria for committee member selection, and that Abramson and Schwarz would be the APSA staff working with this committee. Motion to create the committee was made, seconded, and passed.

Smith then gave some background on the Congressional Fellowship Program. Appointments to the CFP Advisory Committee to date had not gone through the Council. 
Smith noted Abramson recently reached out to Advisory Committee members and then created a list of those who expressed an interest in remaining on the committee and those who will move to emeritus status. Some new members were also being considered and Smith went through those. Three slots for sitting members of Congress on the advisory committee had opened up (one in the House of Representatives and two in the Senate). A motion for the Council to approve future committee appointments as part of the APSA committee appointment process was made, seconded, and approved unanimously.

\section{HELEN DWIGHT REID RENAMING}

Leeds introduced her memo to the Council on the Helen Dwight Reid award's history and funding sources. She then explained why the award renaming committee unanimously recommended naming the award after Merze Tate, the first African American woman to receive her $\mathrm{PhD}$ in government and international relations. Motion to approve the renaming of the Helen Dwight Reid award to the Merze Tate award was made, seconded, and approved unanimously.

\section{DAVID LAKE TASK FORCE}

Lake discussed the purpose and context of his task force and how he would like to address the question of professional research standards back in the discipline. He wanted the task force report to focus on issues of research ethics, data disclosure, and human subject protection. Lake will come to the Council meeting in September with member recommendations, but he was asking the Council for suggestions regarding format and leadership on the task force. Lee, Warren, and Escobar-Lemmon offered their suggestions.

\section{ETHICS COMMITTEE}

Hochschild and Super updated the Council on the meeting of the Committee of Professional Ethics, Right, and Freedoms as well as the sexual harassment issues that were discussed. The Committee proposed a new anti-harassment policy at the Annual Meeting and a pilot project for the role of an ombuds at the Annual Meeting. Lee asked about the consequences that are present for someone who commits harassment. Lake expressed that the Administrative Committee spoke about this and understood that there was currently no manner to punish someone other than referring them back to their home institution. A motion made to adopt the anti-harassment policy was seconded and approved unanimously.
Discussion turned to the role of ombuds. Thies expressed concern over what qualifies someone as an appropriate resource. Hochschild clarified that the ombuds would serve several years. Euben and Lee believed that the proposed solution would not help the issue. Ishiyama underlined the importance of the Council addressing sexual harassment in the profession. Deardorff believed that these resources could put APSA in a position of having to research each grievance. Jamal, Deardorff, Euben, and Mahoney enquired about a consequence to accompany these resources. Lublin and Rothstein expressed concerns that doing nothing will do more harm than good. Hochschild suggested putting together an appropriate response method and follow up. Warren asked Super to clarify the proposal. Lublin would have liked for the motion to clarify the role of the ombuds. He did not think something should be passed merely to serve as a placeholder. Hochschild asked Super to clarify the role of the ombuds. Hochschild then clarified what the Council's alternative was if this proposal was turned down. Lublin wanted to amend the motion to include the specifics brought forward in the memo given to Council. Lake and Escobar-Lemmon would have liked for the word "sexual" to be removed from the title. Motion was made to approve the ombuds and form a committee that would propose a policy at the September Council meeting of appropriate measures in response to reports of harassment. The motion passed.

\section{PUBLICATIONS POLICY COMMITTEE}

F. Lee presented the Publications Policy Committee report. Hochschild gave background on the committee and what the role of the Committee should be. Lublin moved to accept the report and the adoption of its recommendation. Lake seconded Lublin's motion. He expressed that journals have full discretion over editorial policy, but some other issues may arise that this will assist. Hochschild clarified the motion being made by Lublin. Ishiyama saw this as a move toward balance between Council and the journals. Lynch and Leeds discussed the role of the Council in publications. Motion was made, seconded, and approved unanimously.

\section{TEACHING AND LEARNING CONFERENCE}

Smith gave background on the Teaching and Learning Conference (TLC) and what the general opinions of its current form were among members. He then explained that
Council needed to decide if they wanted to continue with the TLC for 2017. He also asked for general feedback on the TLC. Deardorff discussed her thoughts on trying to incorporate the teaching panels into the annual meeting. Motion was made to continue 2017 meeting as well as comprise a committee of consistent and sporadic attendees to address the mission, purpose, and structure of the TLC conference. Motion was seconded and passed unanimously.

\section{MEMBERSHIP CATEGORIES}

Smith explained the work done to improve the APSA dues structure, and the effects that the proposal to charge members for print copies of the journals in 2018 may have. Smith asked the Council for feedback on this change. Chavis was concerned that these changes would affect budget proposals for that year. Smith then explained his proposal to include community college faculty and high school teachers in the professional membership category as well as the change to the Targeted International Member (TIM) category for non-OECD countries. Hochschild outlined the five items the Council should vote on during the meeting. Charging members for print journal copies, deleting the community college and high school teacher categories, and changing the associate membership groups were all tabled until the spring 2016 meeting. Motion to make adjustment to the TIM category as well as the creation of new categories for institutional membership was seconded, and passed unanimously.

\section{The meeting was adjourned at 5:23pm.}

\section{ACTIONS TAKEN BETWEEN APRIL 2016 AND AUGUST 2016 APSA COUNCIL MEETINGS}

On May 23, 2016 after a day of electronic deliberation via email, the Council approved the new American Political Science Review editorial board as proposed by the incoming APSR editorial team by a vote of 21 in favor and 2 opposed.

On May 23, 2016 after a day of electronic deliberation via email, the Council accepted the committee recommendation for the new Journal of Political Science Education editorial team, approving an editorial team consisting of Victor Asal (SUNY Albany) as editor-in chief, with associate editors Mitchell Brown (Auburn University), Shane Nordyke (University of South Dakota), Joseph Roberts (Roger Williams University), Mark Johnson (Minnesota State Community and Technical College), and J. Cherie Strachan 
(Central Michigan University). This motion was approved by a vote of 22 in favor and 1 abstention.

On May 26, 2016 after a day of electronic deliberation via email, the Council approved the Governance Reform Committee's proposed amendment to the proposed APSA bylaws by a vote of 19 in favor and none opposed. The original text and the amended text are included in table 1.

Table 1

Governance Reform Committee's Proposed Amendment to the Proposed APSA Bylaws

\section{ARTICLE 1, SECTION 3 (ORIGINAL TEXT)}

a. The purposes of the Association are to encourage the study of political science, support political scientists in their research, teaching and pub lic engagement, and publish materials related to political science.

b. In achieving these purposes, the Association strongly supports academic freedom.

c. In pursuance of its purposes, the Association has the powers to do all things necessary, proper and consistent with obtaining and maintaining its tax-exempt status under section 501(c)(3) of the Internal Review Code.

\section{ARTICLE 1, SECTION 3 (AMENDED TEXT)}

a. The purposes of the Association are to encourage the study of political science, support political scientists in their research, teaching, and public engagement, and publish materials related to political science.

b. In achieving these purposes, the Association strongly supports academic freedom, freedom of expression, and the equal protection of members and other political scientists regardless of country of origin or residence.

c. In pursuance of its purposes, the Association may not act in any way that is inconsistent with its tax-exempt status under section 501(c)(3) of the Internal Revenue Code. d. The Association as such is nonpartisan and does not support political parties or candidates. The Association encourages individual members in their research, publications, teaching, and public engagement to address significant political and social problems and policies, even when these problems and policies are controversial and subject to partisan discourse. As a corporate body, the Association may take positions on matters of public policy that directly affect its ability to function as an association and conduct business for the good of its members.

\section{New Bylaws Adopted by Members of the American Political Science Association}

In an all-member ballot in October 2016, APSA members voted to adopt the new Bylaws and Articles of Incorporation, as supported and passed by the APSA All-member Business Meeting on September 1, 2016, in Philadelphia, PA. The all-member ballot was conducted electronically, with voting opening on September 30, 2016 for 30 days. 2,143 members voted in favor of adopting the new bylaws and articles of incorporation, 140 voted against incorporation, and 19 members abstained. Turnout was $18.8 \%$. Results were certified by the APSA Election Committee: Janet Box-Steffensmeier (Chair; Ohio State University), Marion Orr (Brown University), and Christina Wolbrecht (University of Notre Dame).

Per the terms of transition set out in the new bylaws, these new bylaws will go into effect at the opening of voting for the next (2017-2018) council member election, anticipated for spring 2017. For more information on the new bylaws, please see www.apsanet. org/ABOUT/Governing-Documents. 